University of Miami Law School University of Miami School of Law Institutional Repository

1991

\title{
Competitive Deregulation of Financial Services Activity in Europe after 1992
}

Caroline Bradley

University of Miami School of Law, cbradley@law.miami.edu

Follow this and additional works at: https://repository.law.miami.edu/fac_articles

Part of the European Law Commons, and the Securities Law Commons

\section{Recommended Citation}

Caroline Bradley, Competitive Deregulation of Financial Services Activity in Europe after 1992, 11 Oxford J. Legal Stud. 545 (1991).

This Article is brought to you for free and open access by the Faculty and Deans at University of Miami School of Law Institutional Repository. It has been accepted for inclusion in Articles by an authorized administrator of University of Miami School of Law Institutional Repository. For more information, please contact library@law.miami.edu. 


\title{
Competitive Deregulation of Financial Services Activity in Europe after 1992
}

\author{
CAROLINE BRADLEY*
}

The internationalization of financial markets is the most important issue facing financial services regulators, firms, and investors today. The EC's 1992 project, which includes attempting to remove the barriers to financial services activity between Member States, and to harmonize the regulation of financial services within the $\mathrm{EC},{ }^{1}$ puts it in a unique position to solve the problems created by the internationalization of financial markets. This article considers the problems caused by internationalization, and whether the EC has made the most of its unique opportunity to deal with these problems.

\section{The Internationalization of World Financial Markets}

Dramatic changes have taken place in world financial markets in recent years. ${ }^{2}$ The internationalization of the markets is not the only source of these changes, but it is the most important source of change, and is a factor which links and makes more problematic all of the other recent developments. For example, an important new phenomenon is the increasing domination of the markets by institutions. Institutions hold an increasingly large percentage of equities, and, as the size of their holdings of investments grows, they can have an increasingly profound effect on the markets, ${ }^{3}$ not only where the institutions are based, but wherever they invest, throughout the world.

- Lecturer in Law, London School of Economics and Political Science. I would like to thank Michael Froomkin, Joe Jacob, Dimity Kingsford-Smith, Peter Muchlinski, Richard Nobles and Dan Prentice for their comments on earlier versions of this article. The errors which remain are my own.

' See the White Paper, Completing the Internal Market (Document Com(85) 310 final, June 1985) which led to the Single European Act of 1986 (OJ No L 169/1, 29 June 1987, reprinted in 25 ILM 506 (1986)) and the 1992 deadline for the achievement of the internal market. See also Lodge, 'The Single European Act: Towards a New Euro-Dynamism?' (1986) 24 Journal of Common Market Studies 203; Glaesner, 'The Single European Act: Attempt at an Appraisal', (1987) 10 Fordham Int'l L 3446.

On the benefits which should accrue from the attainment of the single market, see Commission of the European Communities, 'Research on the "Cost of Non-Europe", Basic Findings', Volume 9, The Cost of Non-Europe in Financial Services, 1988; Cecchini, The European Challenge: 1992 The Benefits of a Single Market, 83 (1988); Emerson, Aujean, Catinat, Goybet \& Jacquemin, The Economics of 1992. The E.C. Commission's Assessment of the Economic Effects of Completing the Internal Market, 98 (1988).

2 See, eg, Carter, Chiplin \& Lewis, eds, Personal Financial Markets (1986) ch 10. See generally Watson, Mathieson, Kincaid, Folkerts-Landau, Regling \& Atkinson, International Capital Markets. Developments and Prospects, January 1988, ch III; Bryant, International Financial Intermediation (1987); 'Symposium: The Internationalization of the Securities Markets', (1986) $4 B U$ Int'l L $\mathcal{F}$ No 1.

${ }^{3}$ See, eg, SEC Staff Report, US SEC Division of Market Regulation, The October 1987 Market Break, CCH Commodity Futures Law Reports, No 322, Special Report, 11 February 1988 ('SEC Staff Report') at ch 3. For a suggestion that the institutions adopt short-term investment policies which are harmful to the cconomy see Lowenstein, What's Wrong with Wall Street (1988).

C Oxford University Press 1991 Oxford Journal of Legal Studies Vol 11, No 4 
Another important development is that governments have deregulated financial markets, removing exchange and interest rate controls, and regulatory authorities have removed controls on commissions, ${ }^{4}$ often in response to deregulation by other governments and regulatory bodies. ${ }^{5}$ Meanwhile, the financial markets have become more integrated: events in derivative markets, such as futures markets, now have a noticeable impact on the underlying markets. The SEC has even concluded that pricing in derivative markets leads price trends in the underlying equity markets. ${ }^{6}$ However, these developments should not be regarded as purely domestic matters, for, as domestic markets have become more integrated, so have international markets. Events in one domestic market may affect another domestic market on the other side of the world. ${ }^{7}$

Firms involved in investment business are constantly developing new markets and new products which are truly international. For example, participants in the euromarkets have produced a wide range of sophisticated instruments and transactions, from swap transactions, which enable parties to those transactions to alter the interest rates or currencies which apply to their payment obligations ${ }^{8}$ to securitization, involving the issue of securities based on various types of income stream, such as interest on mortgage loans. ${ }^{9}$ Financial conglomerates are now involved in activities which range from fund management to corporate finance, and from insurance to commercial banking, and many of these conglomerates are international, formed of entities subject to different jurisdictions and subject to different legal regimes. ${ }^{10} \mathrm{New}$ technology has played an important role in these developments, encouraging integration of markets and the development of new products and new markets. ${ }^{11}$

The internationalization of the markets has advantages, such as allowing investors to diversify across national boundaries more easily. In addition, issuers have access to new sources of capital, and markets should become more liquid,

\footnotetext{
4 On the removal of controls on commissions, see Lorie, Dodd \& Kimpton, The Stock Market. Theories and Evidence (2nd ed 1985); Jarrell, 'Change at the Exchange: The Causes and Effects of Deregulation', (1984) $27 \mathcal{F} L \&$ Econ 273; Gower, 'Big Bang and City Regulation', (1988) 51 MLR 1; Terry, 'The "Big Bang" at the Stock Exchange', (1985) 156 Lloyds Bank Review 16.

'But see Santos, 'On Modes of Production of Law and Social Power', (1985) 13 International fournal of the Sociology of Law 299, 324: 'Deregulations are reregulations.'

- SEC Staff Report, n 3 above, ch 3 at 3-6. See Schick, 'A Review and Analysis of the Changing Financial Environment and the Need for Regulatory Realignment', (1988-9) 44 Bus Law 43 for a suggestion that the stock market and the market for derivative instruments are no longer separate markets, but together form a single equity market and should therefore be regulated by a single regulatory agency.

- See Report of the Presidential Task Force on Market Mechanisms, $\mathrm{CCH}$ Commodity Futures Law Reports, No 319, Special Report, 12 January 1988, Study I The Global Bull Market at I-1: 'The birth of 24-hour markets made all markets functionally and psychologically interlocked"; SEC Staff Report, $\mathrm{n} 3$ above, ch 2,2-2, and ch 11 . These effects were particularly noticeable during the world-wide market crash in October 1987. See SEC Staff Report, $n 3$ above, at ch 2, 2-2.

See, eg, Hazell v Hammersmith and Fulham London Borough Council [1991] 2 WLR 372; Henderson, 'Commodity Swaps: Ready to Boom?' [1989] IFLR 24; Henderson, 'Swap Credit Risk: A Multi-Perspective Analysis' (1989) 44 Bus Law 365; Note Cheng, 'Legal Doctrines Restricting the Secondary Market in Interest Rate Swaps' (1988) 26 Colum 3 Transnat'l L 313.

9 See, eg, Bonsall, ed, Securitisation (1990); Falconer, 'Securitisation in the United Kingdom' [1989] Butterworths $\mathcal{J}$ of $I n t^{\prime} l$ Banking $\mathcal{G}^{\prime}$ Fin $L 105$ and 258.

${ }^{10}$ See Cooper \& Fraser, Banking Deregulation and the New Competition in Financial Services (1984) ch 3.

"Gourgues \& Lauterbach, Revolution in Financial Services, 6 (1987).
} 
more stable, and more efficient. ${ }^{12}$ But the changes also involve new challenges for regulation. For example, investors who buy investment products created in a jurisdiction foreign to them will be faced with selling documents drawn up according to different rules from those in their own jurisdiction, and on the basis of different accounting principles..$^{13}$ Naturally, there is an argument that investors who invest in international investment products are likely to be more sophisticated than the investors for whom investor protection regulation is really designed. Legislators and regulators have relaxed the rules which apply to some transactions, taking account of the prevalence of sophisticated investors in the markets where those transactions occur. ${ }^{14}$ However, it is not only experienced or sophisticated investors who are attracted by the prospect of making larger gains abroad than they could obtain at home. ${ }^{15}$

The development of large financial conglomerates raises issues relating to conflicts of interest, competition and concentration, and supervision of multifunction firms ${ }^{16}$ by single-function regulators. ${ }^{17}$ These issues become even more complex when different elements of the conglomerate are subject to regulation in different jurisdictions. ${ }^{18}$ Effective regulation needs to be flexible enough to be able to cope with new developments in products and markets, but it is also necessary for there to be effective regulation in all the jurisdictions which the products and markets may affect. The combination of all of these changes makes the regulator's job particularly difficult: international financial conglomerates operate throughout the world, as institutions with significant potential to affect the markets, investing in and developing new products.

The integration of markets means that it is increasingly difficult to apply regulation according to national boundaries. Legislation tends to be restricted by

\footnotetext{
12 SEC Staff Report, $\mathrm{n} 3$ above, at ch 11, 11-1. On international diversification see George \& Giddy, eds, International Financial Handbook (1983) s 8.2; Lessard, Principles of International Portfolio Selection.

${ }^{13}$ See Choi \& Levich, The Capital Market Effects of International Accounting Diversity (1990). On the harmonization of accounting standards see, eg, Hopwood, ed, International Pressures for Accounting Change (1989); Blanchet, 'IASC E32 and the Future of International Harmonisation of Accounting' (1989) 6 fournal of International Banking Law 257.

14 See, eg, the Financial Services Act 1986, s48(7); SIB Rules, ch III, The Financial Services (Conduct of Business) Rules 1991, Part 10-Stabilisation; Regulation S, Ofshore Offers and Sales, Securities Act Release No 6863, Exchange Act Release No 27942, Investment Company Act Release No 17458, [1990] Fed Sec L Rep (CCH) II 84524 (24 April 1990); Rule 144a, Resale of Restricted Securities; Changes to Method of Determining Holding Period of Restricted Securities under Rules 144 and 145, Securities Act Release No 6862, Exchange Act Release No 27928, Investment Company Act Release No 17542, [1990] Fed Sec L Rep (CCH) $\pi 84523$ (23 April 1990).

${ }_{15}$ See, eg, Barlow Clowes. Report of Sir Godfrey Le Quesne QC to the Secretary of State for Trade and Industry HC 671, 20 October 1988, ch 8, 60; Parliamentary Commissioner for Administration First Report-Session 198990. The Barlow Clowes Affair HC 76, 19 December 1989, 3-4.

is Conglomerates now carry on banking, insurance, and investment business. See, eg, Maycock, Financial Conglomerates: The New Phenomenon, 75-83 (1986).

${ }_{12}$ Under the Financial Services Act 1986 a functional scheme applies to regulate 'investment business'. One legal entity which carries on a variety of different forms of investment business is regulated under this statute, although detailed regulation applies under the rules of the relevant self-regulating organization ('SRO'). In order to minimize conflicts between these different rules, the regulators have developed the concept of the 'lead regulator'. A member of more than one SRO must comply with the rules of the SRO most appropriate to the activity in question. The UK system does also involve institutional regulation: banks, building societies and insurance companies are all subject to regulation under separate statutory schemes. Generally on regulation of financial services in the UK see Lomax, London Markets after the Financial Services Act (1987).

is See, eg, Kingsford-Smith, "The Regulation of International Financial Intermediaries in the United Kingdom', in Kingsford-Smith, ed, Current Developments in Banking and Finance 89-119 (1989).
} 
reference to territory, ${ }^{19}$ but regulators have to deal with problems which do not fall neatly within territorial limits. ${ }^{20}$

An example may illustrate some of the problems. Alice is a person who produces, in the United Kingdom, a tip-sheet which is distributed only in France. Is Alice carrying on investment business in the United Kingdom for the purposes of the requirement to obtain authorization? Whether or not Alice should be authorized to carry on investment business in the UK, in what other jurisdictions should she obtain authorization to distribute the tip-sheet? What rules govern the terms of the relationship between Alice and the readers of the tip-sheet? If Alice knowingly publishes false information about shares in a company listed on the Luxembourg Stock Exchange and encourages its subscribers to invest in those shares, is an offence of market manipulation committed in France, or in Luxembourg? What law governs whether the investors have a civil remedy against the tip-sheet producer? How is any remedy to be enforced?

Behind all of these familiar questions are other, more important questions. For example, how do the countries with an interest in these events divide between themselves the responsibility for regulation? How does a state protect its own nationals who invest in circumstances where their own state's law cannot help them? What are the incentives for governments and regulators to co-operate in the regulation of financial services activity, or to fail to do so? ${ }^{21}$ How may coordinated regulation take account of the socio-cultural differences which are reflected in financial techniques and regulation in different states? ${ }^{22}$

\section{Solutions to Problems Caused by the Internationalization of the Markets}

Legislators of some states have tried to combat some of the problems of internationalization of the markets by means of a strategy of applying national rules to activity outside their territorial boundaries, and courts have interpreted such municipal legislation as applying to acts abroad which have effects within

\footnotetext{
19 See, eg, s 3 of the Financial Services Act, 1986, which requires authorization for the carrying on of investment business in the UK, and $s 1$, which defines carrying on investment business in the UK. Other provisions of the statute with territorial limitations include $s 47$, which deals with market manipulation (see s $47(5)$ ), and $s 57$, which

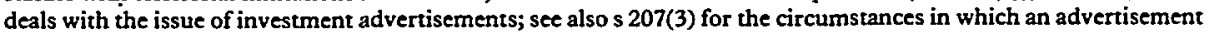
is treated as being issued in the UK.

${ }^{20}$ See SEC Staff Report, Internationalization of the Securities Market, 25 July 1987; Panel on Takeovers and Mergers, 'BAT Industries plc Reasons for the decision of the Appeal Commitree', 29 September 1989; Grass, 'Internationalization of the Securities Trading Markets' (1986) 9 Houston 7 of Int'l L 17. For an example of a court facing problems in international financial markets see, eg, Libyan Arab Foreign Bank v Bankers' Trust [1989] QB 728.

${ }_{21}$ See, eg, Picciotto, 'The Control of Transnational Capital and the Democratisation of the International State' (1988) $15 \mathrm{f}$ of $L$ \& Society $58,71$.

${ }_{22} \mathrm{See}$, eg, Clarich, The German Banking System: Legal Foundations and Recent Trends, EUI Working Paper No 87/269 (1987); Salmonson, 'Problems and Experiences in the Application of the Treaty of Rome to the Insurance Industry" (1966-7) 4 CML Rev 289, 295.
} 
the courts' jurisdiction. ${ }^{23}$ The disadvantage of this approach is that it is likely that other countries, affected by what they see as the extraterritorial operation of the legislation, will be offended and will refuse to assist or even block the activities of the regulators in question. ${ }^{24}$ National rules providing for secrecy in certain circumstances, such as in relation to banking activities, may also impede the effectiveness of extraterritorial legislation. ${ }^{25}$

Co-operative solutions to these problems are likely to be more effective than such unilateral action, but international co-operation in financial regulation involves collective action problems, and states tend to act in their own national interests, ignoring the collective good. ${ }^{26}$ Where states have seen a strong national interest in working with other states, they have acted to promote that interest. For this reason, most attempts to solve the problems of international financial markets have been geared to making enforcement of national laws more effective. For example, states have entered into general multilateral treaties such as the Hague Convention on the Taking of Evidence Abroad in Civil or Commercial Matters, which may be used to obtain information in other jurisdictions. ${ }^{27}$

Other examples of ad hoc collective initiatives are the bilateral agreements to co-operate in the enforcement of regulation, such as those which the US and Japan, ${ }^{28}$ and the US and the UK have concluded. ${ }^{29}$ These are a more satisfactory

${ }^{23}$ See, eg, Leasco Data Processing v Maxwell, 468 F $2 d 1326$ (2d Cir 1972), where US law was applied to a nonresident alien who was held to have engaged in significant conduct in the US in breach of the US securities laws in relation to transactions overseas.

See Goelzer, Mills, Gresham \& Sullivan, 'The Role of the US Securities and Exchange Commission in Transnational Acquisitions' (1988) 22 Int Lawyer 615, 619-20; MacIntosh, 'The Impact of Extraterritoriality on World Banking' in The Institute of Bankers, Competition and Co-operation in World Banking (1985); Grossfeld \& Rogers, 'A Shared Values Approach to Jurisdictional Conflicts in International Economic Law', (1983) 32 ICLQ 931; Maier, 'Extratertitorial Jurisdiction at a Crossroads: An Intersection between Public and Private International Law', (1982) 76 Am J Int'l L 280.

24 Sec, eg, the Protection of Trading Interests Act 1980, which was introduced to combat the extraterritorial effects of US anti-trust rules, but which may be used against any country, and in a wide range of circumstances.

${ }_{25} \mathrm{Sec}, \mathrm{eg}$, Szat, 'International Co-operation in Insider Trading Cases', (1983) 40 Washington and Lee L Rev 1149. There are, however, moves to combat secrecy in certain circumstances. See, eg, Opinion on the proposal for a Council Directive on prevention of the use of the financial system for the purpose of money laundering, OJ No $C$ 332/86, 31 December 1990.

${ }_{26}$ See Bryant, $\mathbf{n} 2$ above, ch 8, suggesting the need to evolve international political institutions; and, on collective action generally, see Hirsch, Social Limits to Growth (1976); Olson, The Logic of Collective Action (1971).

${ }^{27}$ Opened for signature, $18 \mathrm{March} 1970,23$ UST 2555. For an example of an application under this Treaty in England to obtain information on a revenue matter see Re State of Norway's Applications (Nos 1 and 2) [1990] 1 AC 723. Also see the Santa Fe case for successful use of this convention in a securities matter: SEC v Certain Unknown Purchasers of Common Stock Civ No 81-6553 (SDNY 1986), afrd, 817 F 2d 1018 (2d Cir 1987), cert denied, 56 USLW 3568 (US, 23 Feb 1988). See also Casenote, Minch, "US Obligations under the Hague Evidence Convention: More than Mere Good Will?', (1988) 22 Int Lawyer 511 ; Criminal Justice (International. Cooperation) Act 1990.

${ }_{29}$ Sec "Japan-US Memorandum of the US Securities and Exchange Commission and the Securities Bureau of the Japanese Ministry of Finance on the Sharing of Information', 23 May 1986, reprinted in 25 ILM 1429 (1986).

${ }^{29}$ See 'UK-US Memorandum of Understanding on Exchange of Information in Matters Relating to Securities and Futures', 23 September 1986, reprinted in 25 ILM 1431 (1986). See also 'Canada-US Memorandum of Understanding on Administration and Enforcement of Securities Laws', reprinted in 27 ILM 412 (1988); Goclzer, Mills, Gresham \& Sullivan, "The Role of the US Securities and Exchange Commission in Transnational Acquisitions', (1988) 22 Int Lawyer 615, 636-41.

The US International Securities Enforcement Cooperation Act of 1990 is designed to improve international cooperation in the enforcement of securities laws and to allow the SEC to restrict the activities in the US securities markets of those who have been engaged in misconduct in other countries. See International Securities Enforcement Cooperation Act of 1990, Securities Reforms of 1990, CCH Fed Secs L Reps No 1424, 6 December 1990, Part II, 106. Cf Part III of the UK Companies Act 1989, dealing with powers to assist overseas regulatory authorities; see also The Securities and Investments Board, The Financial Regulation of Overseas Institutions with UK Branches. A Consultative Document, March 1988. 
solution to the problem of enforcing national rules in the context of international markets, and an important development. At present, however, the bilateral agreements which exist are not sufficiently comprehensive to be really effective. These agreements are designed to help regulators to obtain information from their counterparts in other jurisdictions, but they are not helpful if the foreign regulators are inefficient, or if the foreign law does not regulate the activities in question.

A completely new solution to the problems caused by international markets would be the creation, through multilateral agreements between many states, of a transnational regulatory body, or several such bodies, and the acceptance of common principles for regulation. ${ }^{30}$ The programme which the EC is adopting to achieve the single internal market in financial services is a solution of this type, ${ }^{31}$ although the EC has not yet created a single Euro-regulator for financial services activity, but instead relies on regulation by national authorities. ${ }^{32}$ The EC scheme should enhance the effectiveness of national rules where extranational elements are present, and is designed to result in a common core of principles and rules applied in a territorial area occupied by many separate states. ${ }^{33}$ The existing relationships between the members of the EC produce incentives for them to work together to achieve these aims, but the Member States still have other incentives to protect their own national interests, which may frustrate the attainment of these aims.

Each Member State retains its national interest in ensuring that it benefits from financial activity within the Community. National governments say that

\footnotetext{
${ }^{30} \mathrm{Cf}$ the activities of the Cooke Committee in promoting co-operation between banking supervisory authorities, and those of IOSCO in promoting co-operation between securities regulators. See, eg, Bryant, $n 2$ above, 144-9.

31 A major element of the programme to achieve the single market in financial services context is the Second Banking Directive. (Second Council Directive on the co-ordination of laws, regulations and administrative provisions relating to the taking up and pursuit of the business of tredit institutions and amending Directive 77/ 780/EEC (89/646/EEC) OJ No L 386/1, 30 December 1989.) This Directive illustrates the 'new approach' which the Commission has adopted to speed up the process of co-ordination of national laws since the 1985 White Paper. The old approach involved the adoption of detailed harmonization measures. In contrast, the new approach concentrates on harmonization of essential standards for prudential supervision, so that the Member States can recognize each other's supervisory systems and accept each other's authorizations to carry on banking business. A bank authorized to carry on banking business in one Member State should be able to carry on banking business throughout the Community. Prudential supervision is to be carried out by the State in which a bank has its head office, and is authorized (described as its 'home' State). Any other State where this bank establishes a branch, or where it provides services to customers will be described as a 'host' State.

For the background to the Second Banking Directive see Zavvos, 'The Integration of Banking Markets in the EEC: The Second Banking Directive' (1988) 2 fournal of Intemational Banking Law 53. See also Zavvos, 'Towards a European Banking Act' (1988) 25 CML Rev 263.

${ }_{32}$ Subject to the overall supervision of the EC Commission: the Commission has the power to bring enforcement proceedings against Member States which do not comply with the Treaty of Rome or EC legislation. See Articles 169-71 Treaty of Rome, and see Hartley, The Foundations of European Community Law (2nd ed 1988) ch 10; Dashwood \& White, 'Enforcement Actions under Articles 169 and 170 EEC' (1989) 14 EL Rev 388.

${ }_{33}$ See, eg, Hopt, 'The European Insider Dealing Directive' (1990) 27 CML Rev 51 and Note, McGuinness, 'Toward the Unification of European Capital Markets: The EEC's Proposed Directive on Insider Trading' (1988) 11 Fordham Int'l E $\mathcal{f} 432$, describing EC harmonization as a step to global co-operation. Generally on the harmonization process see: Vogelaar, 'The Approximation of the laws of Member States under the Treaty of Rome' (1975) 12 CML Rev 211 (arguing, at 213, that harmonization 'has a law-making function quite independent of compromises as between national provisions'). See also Roth, 'The European Economic Community's Law on Services: Harmonisation' (1988) 25 CML Rev 35.
} 
they regulate financial services to protect investors so as to ensure that funds are available for national industry. ${ }^{34}$ When a state's financial markets are dominated by national savers and borrowers the Government of that state must act to protect those savers and borrowers in order to stay in power. However, when savers and borrowers in a nation's markets are largely foreign, and national savers and borrowers are involved in foreign markets, the connection between investor protection and votes is weakened. In these circumstances the state's real interest in its financial markets, and the Government's, is not in the encouragement of investment by protecting investors, but in the capture of the employment and revenue produced by those markets, even at the expense of other states in the Community.

In practical terms, internationalization means that national authorities lose a significant degree of control over the national economy, ${ }^{35}$ and over protection of national savers and borrowers. It also means that regulatory priorities may change: regulation is likely to be designed to attract business, rather than to provide the highest possible degree of protection for small investors. The probable result is a competition between different national regulators to develop regulation which is attractive to financial services firms rather than to investors.

\section{Competitive Deregulation}

\section{The Start of the Race}

The EC legislation and proposals for legislation which are designed to achieve the single market in financial services provide for minimum standards which must be adopted by the Member States. ${ }^{36}$ However, these minimum standards may not yet be adequate. ${ }^{37}$ The politics of the legislative process in the EC often results in harmonization Directives, which are 'watered down to make them politically acceptable'. ${ }^{38}$ ch 1 .

4. See, eg, Financial Services in the United Kingdom. A new framework for investor protection Connd 9432 (1985),

${ }^{35}$ See Bryant, $n 2$ above, $91-4$.

36 For example, the Second Banking Directive, $\mathrm{n} 31$ above, establishes minimum requirements for initial capital, for investigation of the suitability of those who are in a position to exert a significant influence over the bank's management, and for approval and supervision of such persons, for controlling the extent of and nature'of banks' own holdings in other companies, and for professional secrecy obligations imposed on banking regulators and their employees. The imposition of such minimum requirements was necessary to persuade Member States to agree that a banking licence granted by one Member State should be effective throughout the Community.

37 An example of the way in which the EC's rules set out these minimum standards is Article 11(1) of the proposed Investment Services Directive. See Amended proposal for a Council Directive on investment services in the securities field $(90 / C 42 / 06)$, OJ No C 42/7, 22 February 1990, and EC Investment Services Directive. $A$ Consultative Document. DTI, July 1990. This provision states that the home Member State's prudential rules must require sound administrative and accounting procedures and internal control mechanisms, the separation of clients' and firm's money and securities, membership of compensation schemes to protect investors, the provision of information to the competent authorities, the keeping of adequate records, and that firms are organized in such a way that conflicts of interest between the firm and its clients or between one of its clients and another do not result in clients' interests being prejudiced. This is a minimum standard which does nothing to suggest appropriate contents for these types of prudential rule.

${ }^{38}$ Pelkmans, Market Integration in the European Community 183 (1984). However, for a suggestion that minimum standards are adequate, see Zavvos, 'Towards a European Banking Act', (1988) 25 CML Rev 263, 269. 
An examination of the Second Banking Directive and the proposed Investment Services Directive, ${ }^{39}$ which have both involved a difficult negotiation process, ${ }^{40}$ illustrates some of the difficulties the Community faces in developing legislation acceptable to all Member States. Banks and investment firms will be subject to minimum capital requirements in the EC after $1992,{ }^{41}$ but capital requirements alone cannot achieve all of the goals of financial regulation. In addition to capital requirements, conduct of business rules are necessary in order to prevent abuses such as churning, whereby financial intermediaries managing client funds could deplete those funds and line their own pockets with commissions. Both the Second Banking Directive and the proposed Investment Services Directive fail to harmonize conduct of business rules because Member States could not agree on what such rules should cover. ${ }^{42}$ This failure may have serious consequences, as conduct of business rules are an exception to the general rule that banks (and investment firms) are to be regulated by their home state. The Second Banking Directive, and the proposed Investment Services Directive allow host states to regulate the conduct of business. ${ }^{43}$ The Commission intends that co-ordination of conduct of business rules will take place in the future. Until that happens the conduct of business rules which currently apply in the host Member State as a matter of national law or industry practice will apply, and investment firms which carry on business in more than one Member State will probably need to comply with a different set of rules in each State. Such firms will, therefore, need to invest resources in different compliance systems. Host

\footnotetext{
39 See $\mathbf{n} 37$ above.

40 See, eg, Waters, 'Seeking EC Consensus on Financial Services', Financial Times, 15 May 1991, 32, col 8. Cf Venit, 'The "Merger" Control Regulation: Europe Comes of Age . . or Caliban's Dinner' (1990) 27 CML Rev 7, 8-11.

${ }^{41}$ See DTI, EC Capital Adequacy Directive. A Consultative Document, September 1990; Proposal for a Council Directive on Capital Adequacy of Investment Firms and Credit Institutions, Com(90) 141 final, OJ No C 152, 21 June 1990; Council Directive on the own funds of credit institutions (89/299/EEC) OJ No L 124/16, 5 May 1989; this Directive defines what may constitute a credit institution's capital; Council Directive on a solvency ratio for credit institutions (89/647/EEC) OJ No L 386/14, 30 December 1989. See Spencer \& Murray-Jones, "Capital Adequacy: Towards a Level Playing Field' [1988] IFLR 19, at 20-21; Note, Chang, 'The Proposed Risk-Based Capital Framework: A model of International Banking Co-operation?' (1988) 1 I Fordham Int'l L J 777, at 794-800; Commission Recommendation on monitoring and controlling large exposures of credit institutions (87/62/EEC) OJ No L 33/10, 4 February 1987; Commission Recommendation concerning the introduction of deposit guarantee schemes (87/63/EEC) OJ No L 33/16, 4 February 1987; Proposal for a Council Directive on monitoring and controlling large exposures of credit institutions OJ No C 123/18, 9 May 1991.

${ }^{42}$ For example, the proposed Investment Services Directive does not attempt to co-ordinate the conduct of business rules regulating the relationship between investment firms and their clients, because "there are considerable divergences between Member States in the content of such rules and in the way in which they are applied'. (See the Explanatory Memorandum to the proposed Investment Services Directive, Com(88) 778- SYN 176 , OJ No C 43/7, 22 February 1989, section I.)

${ }^{43}$ See, eg, Article 21.5 of the Second Banking Directive, $\mathrm{n} 31$ above, which provides that host Member States may enforce the 'legal rules they have adopted in the interest of the general good'. Under this provision a Member State may apply its own rules, adopted in the interest of the general good, even if, in doing so, it prevents a bank authorized in another Member State from acting in a way that would be allowed in its home country. Cf Proposal for a Third Council Directive on the coordination of laws, regulations and administrative provisions relating to direct life assurance and amending Directives 79/267/EEC and 90/619/EEC, OJ No C 99/2, 16 April 1991, Recital 18 , and Articles 35 and 36 , which appears to be more restrictive.

The Proposal for a Council Directive on unfair terms in consumer contracts, OJ No C 243/2, 28 Septernber 1990 , will affect the relationships between those involved in investment business, and consumers. The proposed Directive would require Member States to prohibit unfair terms in consumer contracts, and this proposal therefore goes some way towards the harmonization of conduct of business rules.
} 
country rules regulating compensation schemes will also apply to branches of investment businesses authorized in other Member States pending further harmonization. ${ }^{44}$

The EC's programme to achieve the single market in financial services uses the Directive, a flexible legislative instrument which requires Member States to enact legislation which will achieve a particular result. ${ }^{45}$ Member States may, however, choose the form and method of implementation. ${ }^{46}$ The use of such a legislative tool has advantages, in that it allows the application of legislative provisions to be tailored to particular cases, but the interests of investors and depositors may suffer where the minimum standards laid down in a Directive are weak, and national authorities are unwilling to take stronger action. Because the Directives impose minimum standards, the requirements actually imposed by the Member States may vary enormously in scope and stringency. ${ }^{47}$ In addition, the use of Directives to achieve harmonization causes many small differences between national laws. ${ }^{48}$ In theory, interpretative rulings by the European Court under Article 177 of the Treaty of Rome should reduce the differences between national laws, so that EC rules are applied similarly in all of the Member States, ${ }^{49}$ but interpretative rulings cannot solve the problems caused by inadequate measures in a Directive. Equal application of inadequate rules is unsatisfactory.

In practice, there are often significant delays in the implementation of Directives, ${ }^{50}$ and it is not clear that the Commission's enforcement proceedings

\footnotetext{
4. The proposed Investment Services Directive, $n 37$ above, Article 11(1).

45 Although Directives are not directly applicable according to Article 189 of the Treaty of Rome, unlike Regulations, they may have direct effect, see Van Duyn v Home Office, Case 41/74 [1974] ECR 1337. Directives may create individual rights which municipal courts must recognize after the time limit for their implementation has passed, see Ratti, Case 148/78 [1979] ECR 1629.

In order to produce direct effects, a measure must be legally valid from the point of view of national courts, and the terms of the provision must be appropriate to confer rights on individuals. The provision must be clear and unambiguous, and unconditional, and its operation must not be dependent on further action being taken by Community or national authorities. See Hartley, n 32 above, ch 7 at 188; Schermers \& Waelbroeck, fudicial Protection in the European Communities (4th ed 1987) ('Schermers \& Waelbroeck') at 124-37. See also Winter, 'Direct Applicability and Direct Effect-Two Distinct and Different Concepts in Community Law' (1972) 9 CML Rev 425; Timmermans, 'Directives: Their Effect within the National Legal Systems' (1979) 16 CML Rev 533.

46 In some circumstances the Member States' discretion about how to implement a Directive can be limited, depending on the objective to be achieved; for example, in Enka, Case 38/77 [1977] ECR 2203, the European Court held that the relevant provision should be introduced in the same way in each Member State; but cf Commission $v$ Italy, Case 363/85 [1987] ECR 1733. In Commission v Italy, Case 300/81 [1983] ECR 449, the Court held that it was not appropriate to implement a Directive by means of administrative procedures, and that implementation must be clear and certain, and not subject to the risk of being changed at the whim of the authorities. In Commission v Belgium, Case 301/81 [1983] ECR 467, the Court held that a Member State could not plead internal problems to excuse a failure to implement a Directive.

"See Cary, 'Federalism and Corporate Law: Reflections Upon Delaware', (1974) 83 Yale L $7663,701-3$ for a suggestion that the imposition of federal minimum standards of conduct for management and corporations could resolve the problems caused for investors by the competition in laxity between the States in the United States of America in the context of corporate law. Cary points out that a federal minimum standard, once interpreted by the federal courts, could then be applied by state courts, and uniform rules would apply throughout the USA.

is Pelkmans, Market Integration in the European Community 157 (1984).

49 See, eg, Litster v Forth Dry Dock \& Engineering Co Ltd [1990] AC 546.

so See, eg, Gaja, 'New Developments in a Continuing Story: The Relationship between EEC Law and Italian Law' 27 CML Rev 85, 89-93 (1990). In Re Stock Exchange Listing Directives (Case 390/85 [1988] 1 CMLR 146) the European Court held that Belgium's problems in implementing the listing Directives did not excuse their nonimplementation. Belgium had argued that its difficulties derived from the large number of points the legislation covered, the lack of precision of the Directives, which meant that the Member States had to develop precise rules, and the complexicy of the national procedures involved.
} 
are effective in ensuring compliance with Community legislation. The Commission has expressed concern about the failure of Member States to comply with judgments of the European Court of Justice, which 'undermines the fundamental principle of a Community based on law'. ${ }^{1}$ Hartley has suggested that, '[s]ince the Community mechanism functions only if there is mutual trust and good.will between the Member States and Community Institutions, excessive resort to enforcement actions might do more harm than good'.$^{52}$

The ability of individuals to rely on the direct effects of Directives which have not been implemented within a Member State, or which have been inadequately implemented, before the courts of that State can be an important additional mechanism for the enforcement of Community law, ${ }^{53}$ and the European Court has held that individuals may rely on provisions of Directives against bodies responsible for providing a public service under the control of the state, whatever their legal form. ${ }^{54}$ Presumably, regulatory bodies such as the Securities and Investments Board, the Stock Exchange and the Panel on Take-overs and Mergers would be in a position analogous to that of British Gas, so that individuals should be able to rely on provisions of relevant Directives against these bodies. ${ }^{55}$ However, although some provisions of the Directives which should facilitate the creation of the single market in financial services seem to be sufficiently clear and precise to give rights to individuals, ${ }^{56}$ others do not.

Divergence between national laws within the EC may be caused by the sensitivity of businesses and governments to the risk of driving business offshore. ${ }^{57}$ It is possible that a Member State might decide to encourage financial institutions to subject themselves to its jurisdiction by imposing only the minimum requirements laid down in the relevant Directives. ${ }^{58}$ Such financial institutions would benefit from a real competitive advantage $e^{59}$ over financial institutions subject to more severe rules laid down in another jurisdiction. All financial institutions would have a strong incentive to choose to be regulated under the most relaxed system. This in turn would provide an incentive for all other Member States to relax their own rules in the hope of attracting financial institutions to their jurisdiction, or preventing flight from it. This is the famous

\footnotetext{
31 See the Sixth Annual Report to the European Parliament on Commission monitoring of the application of Community Law 1988, Com(89) 411 final, OJ No C 330/1, 30 December 1989, at 6.

52 Hartley, $\mathrm{n} 32$ above, at 293.

33 See, eg, Steiner, 'Coming to Terms with EEC Directives', (1990) $106 L Q R$ 144, 145.

54 Foster v British Gas, Case C 188/89, (1991] 2 WLR 258.

3s Cf $R$ v Panel on Take-overs and Mergers ex p Datafin [1987] QB 815.

S6 See $\mathrm{n} 45$ above.

57 See, eg, 'The Single European Market: survey of the UK financial services industry', Bank of England Quarterly Bulletin, August 1989, 407, at 409: 'It was felt . . . that the United Kingdom needed to make efforts to retain its competitiveness, and that the authorities needed to ensure that the regulatory environment did not reduce the attractions of the UK market.'

${ }^{58}$ For a reference to the idea that there may be a 'competition of standards' in the EC, see Meessen, 'Europe En Route to 1992: The Completion of the Internal Market and its Impact on Non-Europeans' (1989) 23 Int Lawyer 359 , at 366.

59 The competitive advantage would derive from reduced costs of compliance. As to costs imposed by regulation see, eg, Winter, 'State Law, Shareholder Protection, and the Theory of the Corporation' (1977) 6 I Leg Stud 251, 258-62; Stigler, 'Public Regulation of the Securities Markets' (1964) 37 f Bus 117.
} 
'race to the bottom' ${ }^{60}$ Already, there are signs that this race is beginning: the International Stock Exchange in London relaxed its rules for euro-currency securities in April 1989, ${ }^{61}$ and announced further relaxations to its rules, including a reduction in the length of the trading record required of companies admitted to the Official List and the Unlisted Securities Market, in February $1990 .^{62}$ The Bank of England has stated that: 'The need to maintain and enhance London's competitiveness as an international financial centre continues to be an object of the Bank's supervision'. ${ }^{63}$

The only inevitable benefits which would accrue to a Member State seeking to market a relaxed regulatory regime would be the fees it could charge for authorization, and subsequent periodic fees. The real revenues to be gained from financial services firms would derive from sources such as taxes, and employment, rather than from fees imposed by the regulatory authorities. In any event, Member States will remain obliged to impose some regulation in order to comply with their EC obligations, which will reduce their opportunity to profit from regulation. The real benefits will arise where firms carry on business. In theory, financial services firms are supposed to be subject to the rules that their home state imposes on them, but they will also be affected by rules in the states where they carry on business. ${ }^{64} \mathrm{It}$ is the failure to harmonize conduct of business rules which may lead to a meaningful competition in laxity.

The method of co-ordination which the Community has adopted will not inevitably result in competitive deregulation. It is possible that some institutions would consider that the investor and depositor confidence which would result from regulation under a strict system could outweigh the competitive advantage provided by regulation under a relaxed system. A Member State could market its regulatory system as a system of tough and effective regulation designed to promote investor confidence. This is the 'struggle to the top'. ${ }^{65}$ The Stock Exchange in London has recently begun to market a listing in London as a product which can ensure investor confidence, ${ }^{66}$ although at the same time

\footnotetext{
60 For arguments that there is a race to the bottom see, eg, Cary, $\mathrm{n} 47$ above; Weiss \& White, 'Of Econometrics and Indeterminacy: A Study of Investors' Reactions to "Changes" in Corporate Law', (1987) 75 Calif L Rev 551, 554-9; Fox, 'The Role of the Market Model in Corporate Law Aralysis: A Comment on Weiss and White', (1988) 76 Calif $L$ Rev 1015 at $1042-5$. See also Bryant, n 2 above, at 129.

61 For the new rules see Admission of Securities to Listing, issued by authority of the Council of the Stock Exchange, November 1984, s 7 .

${ }_{62}$ See FitzSimons, 'EC Directives Change Securities Markets', Financial Times, 15 February 1990, 37, coll.

${ }_{63}$ See Bank of England Banking Report for $1989 / 9013$ (1990).

of On the factors which may influence the development of financial centres see Kindleberger, Economic Response. Comparative Studies in Trade, Finance, and Growth (1978) ch 4, predicting, at 134, 'very tentatively' that Brussels would eventually be the EC's financial centre. For a suggestion that businesses will not become involved in regulatory arbitrage see Price Waterhouse, Banking and Securities Regulation in Europe. A Survey of Senior Management Views (1990).

${ }_{65}$ For the view that the state corporate legal systems protect shareholders see, eg, Winter, $\mathrm{n} 59$ above, at 276; Fischel, 'Efficient Capital Market Theory, the Market for Corporate Control, and the Regulation of Cash Tender Offers', (1978) 57 Tex L Rev 1, 28-9; Romano, 'Law as a Product: Some Pieces of the Incorporation Puzzle', (1985) if L Econ E Organization 225; Romano, 'The Political Economy of Takeover Statutes', (1987) 73 Va L Rev 111, 121-2, 189; Macey \& Miller, 'Toward an Interest-Group Theory of Delaware Corporate Law', (1987) 65 Tex $L$ Rev 469; Easterbrook, 'Antitrust and the Economies of Federalism', (1983) 26 J L \& Econ 23; Baysinger \& Butler, 'The Role of Corporate Law in the Theory of the Firm', (1985) 28$\} L$ G Econ 179.

\& The International Stock Exchange, $A$ Listing in London. See also recent advertisements for NASDAQ, for example: NASDAQ 'offers . . . the proven efficiency, liquidity and regulatory standards of a screen-based electronic market', Financial Times, 15 February 1990, at $3 \mathrm{col} 4$.
} 
relaxing its rules. It is a small step from marketing an investment market to the marketing of an entire regulatory system.

It is clear that each Member State will have an interest in developing its own system as the leader of the EC regulatory systems for financial services, and in making its system the most popular. The possession of such a system would provide considerable advantages to that Member State in terms of revenue and employment if financial services firms were to carry on business in that Member State. The advantages are the foundation for a serious conflict between the interests of that Member State as part of the Community as a whole, and its own national interests. ${ }^{67}$ These problems are not new, and they are not unique to the EC. The ongoing discussion about Delaware's race to the bottom in the context of corporate law in the United States provides food for thought in the European context.

However, the parallel is not exact. In the United States it is possible to remedy defects in the corporate law of the states through federal securities rules, and to ensure that states adopt a single interpretation of federal law. EC legislative provisions do lay down minimum standards, but there are weaknesses in the EC mechanisms for ensuring compliance by Member States with their EC obligations, and for ensuring comparable interpretations of provisions of EC legislation in different Member States.

Thus, the debate about whether the States are racing towards the lowest possible level of corporate law in the US, and about possible solutions to this problem, if it exists, may not be directly relevant to the EC's single market in financial services. There may be significant differences between the market for corporate law and the market for investor and depositor protection rules. Even if Winter is correct in saying that investors can ensure the existence of the corporate law regime which protects their interests, ${ }^{68}$ it is not clear that the same argument would apply to the market for investor and depositor protection rules. Shareholders are not entirely reliant on the protection provided by corporate law, partly because they enjoy some protection by market forces. The market for corporate control may, for example, provide protection for shareholders in companies with inefficient managements. ${ }^{69}$ There is, however, no market-based equivalent to investor and depositor protection rules, because those rules are intended to remedy market failures. ${ }^{70}$

\footnotetext{
${ }^{67}$ Co-ordination of national laws is supposed to involve the adjustment of national law so that solutions are adopted which take account of national interests and also of the interests of other Community partners, a real change in the national law-making process. See Vogelaar, $\mathrm{n} 33$ above, at 211 .

$\omega$ See Winter, $\pi 59$ above.

${ }^{69}$ See, eg, Manne, 'Mergers and the Market for Corporate Control' [1965] Journal of Polítical Eeonomy 110; Manne, 'Some Theoretical Aspects of Share Voting', (1964) 64 Col L Rev 1427; Marris, The Economic Theory of 'Managerial' Capitalism (1964); Fama \& Jensen, 'Agency Problems and Residual Claims', (1983) $26 f L E$ 'Econ 327; Fama \& Jensen, 'Separation of Ownership and Control', (1983) $26 f$ L E' Econ 301; Fischel, 'Efficient Capital Market Theory, the Market for Corporate Control and the Regulation of Cash Tender Offers', (1978) 57 Tex $L$ Rev 1; Easterbrook \& Fischel, 'Corporate Control Transactions', (1982) 91 Yale $L$ f 698; Jensen \& Ruback, 'The Market for Corporate Control: The Scientific Evidence', (1983) 11 fournal of Financial Economics 5.

${ }_{70}$ See, eg, Gordon, 'Ties That Bind: Dual Class Common Stock and the Problem of Shareholder Choice', (1988) 76 Calif L Rev 1, 68-9.
} 


\section{Ending the Race?}

It was not always inevitable that the EC would choose to regulate financial services in the way that it has. For example, commentators have suggested that there should be an EC Securities and Exchange Commission. ${ }^{71}$ It has been suggested that, although powers could be given to the national authorities, it was 'seriously worth considering whether the primary implementation by national authorities should not be supplemented by a subsidiary power of intervention on the part of a community organ'. ${ }^{72}$ The introduction of an EC supervisory authority with responsibilities in the financial services sphere would help to ensure that rules would be applied in the same way in all Member States, but the creation of such a body would entail extensive amendment of the EC's financial services legislation, and it is therefore unlikely that a Euro-regulator for financial services will be set up in the near future. The Commission will be responsible for exercising supervisory functions in the single market in financial services, and the Commission is capable of acting as a fierce regulator, but the Commission is not capable of regulating financial services activity directly, except in the context of the EC competition rules, ${ }^{73}$ because its functions are limited to ensuring that national regulation complies with the requirements of the EC rules. The Commission will not be a supranational securities regulator.

Although there is no Euro-regulator for financial services, the EC is aware of the risks of competitive deregulation within the single internal market in financial services. The preamble to the Second Banking Directive states that Member States should not authorize banks which appear to be trying to avoid the stricter rules of another Member State. ${ }^{74}$ However, the Recital expresses no more than a pious hope, because the operative provisions of the Directive do nothing to force the supervisory authorities in the Member States to turn away banks applying for authorization. This hope will not avert a race to the bottom in the single market in financial services, and, if such a race does occur, resulting in the development of one or more financial centres in the EC, it is unlikely that future harmonization of regulation within the EC could reverse this development, so it would be desirable for the EC to act to prevent competitive deregulation before the 1992 deadline.

"See (1976) 13 CML Rev 147-277 Special Issue on the Economic Law of the Member States in an Economic and Monetary Union. Report by Hopt at 245.

"2 Ibid at 250. See also Leleux, 'Corporation Law in the United States and in the EEC', (1967-8) 5 CML Rev 133 suggesting the need for a European agency responsible for securities regulation based on the American model, at 159:

'[H]armonization presents very great difficulties when the actions of the authorities in the various countries are based on different ideas, and even if harmonization is achieved, the disadvantages of having parallel but multiple procedures that have to be gone through are obvious.'

73 On the competition law of the EC, see generally: Wyatt \& Dashwood, The Substantive Law of the EEC (2nd ed 1987) Part VII, 341-474. See also the Council Regulation on the Control of Concentrations Between Undertakings, No 4064/89, OJ No L 395/1, 30 December 1989.

" Second Banking Directive, $\mathrm{n} 31$ above, Recital number 8: 'the principles of murual recognition and of home Member State control require the competent authorities of each Member State not to grant authorization or to withdraw it where factors such as the activities programme, the geographical distribution or the activities actually carried on make it quite clear that a credit institution has opted for the legal system of one Member State for the purpose of evading the stricter standards in force in another Member State in which it intends to carry on or carries on the greater part of its activities'. 


\section{Conclusion}

International financial markets pose new problems for market participants, investors and regulators, and so far no satisfactory solutions have been found for these problems. The steps which states have taken to improve the enforcement of their own domestic rules do not deal with the real problem, because what is needed is an international solution to these international problems. However, there are significant barriers to the achievement of such a solution in the cultural differences between different states, which produce different attitudes to regulation, and in the need of governments to become involved in international initiatives only when the interests of their own state demand such involvement.

The EC rules which are designed to create the single internal market in financial services are the basis of an important attempt to develop common approaches in countries with diverse economic and social environments, and the development of the rules is an impressive achievement. The existing relationships between the Member States of the EC have removed some of the barriers to a multi-lateral approach to financial regulation, but although the Member States see an advantage in their membership of the EC, they also see an advantage in protecting their own national position.

The result of this conflict is that there are weaknesses in the EC's rules for the single market in financial services. First, there is considerable doubt whether the minimum standards set out in the Directives provide an adequate basis for regulation. Second, the EC still relies too much on territorial concepts which are no longer appropriate to modern financial markets. This reliance on territorial concepts leaves too much scope for individual action by the Member States, which could interfere with the development of the single market. Individual action by Member States is likely to lead to competitive deregulation of financial services within the EC, so that only the inadequate minimum standards imposed by those Directives prevail. As a result, it is likely that the single market will become a market in which lax regulatory standards prevail, and that existing institutional mechanisms will be powerless to prevent or remedy the situation. 